\title{
HUBUNGAN MINAT BACA DENGAN PRESTASI BELAJAR BAHASA INDONESIA BAGI SISWA KELAS VI SD NEGERI 57 BULU-BULU KECAMATAN MARUSU KABUPATEN MAROS
}

\author{
Andi Adam. \\ Pendidikan Guru Sekolah Dasar, Fakultas Keguruan dan Ilmu Pendidikan \\ Universitas Muhammadiyah Makassar \\ Iqramsyar34@gmail.com
}

\begin{abstract}
ABSTRAK
Masalah utama dalam penelitian ini adalah apakah terdapat hubungan yang signifikan antara minat baca dengan prestasi belajar Bahasa Indonesia bagi siswa kelas VI SD Negeri Bulu-bulu Kecamatan Marusu Kabupaten Maros. Penelitian ini bertujuan untuk mengetahui bagaimana hubungan antara minat baca dengan prestasi belajar Bahasa Indonesia bagi siswa kelas VI SD Negeri Bulu-bulu. Jenis penelitian ini adalah penelitian korelasional yang bertujuan untuk mengetahui hubungan minat baca dengan prestasi belajar Bahasa Indonesia bagi siswa kelas VI SD Negeri Bulu-bulu. Sampel dalam penelitian ini adalah murid kelas VI SD Negeri Bulu-bulu sebanyak 37 orang murid. Pengambilan data dilakukan dengan menggunakan tes hasil belajar bahasa Indonesia, serta angket minat baca murid untuk mengetahui respon murid terhadap pembelajaran. Adapun hasil analisis deskriptif yang diperoleh sebagai berikut. (1) Hasil belajar yaitu, dari 37 orang murid, terdapat 35 orang murid yang berada pada kategori tuntas dengan persentase 94,59\%, dan 2 orang murid yang berada pada kategori tidak tuntas dengan persentase 5,40 \%. Skor rata-rata yaitu, 80,14 yang berada pada kategori tinggi. (2) Respon murid terhadap minat baca murid berada pada kategori sedang dengan rata-rata yaitu 58,08. Adapun hasil analisis inferensialnya yaitu, $r$ hitungnya sebesar 0,738 dan $r$ tabel sebesar 0,418. Dengan demikian 0,738 $>0,418$. Dimana $r_{\text {hitung }}>r_{\text {tabel }}$, berarti $H_{0}$ ditolak dan $H_{1}$ diterima. Berdasarkan hasil penelitian di atas, maka dapat disimpulkan bahwa terdapat hubungan yang signifikan antara minat baca dengan prestasi belajar Bahasa Indonesia bagi siswa kelas VI SD Negeri 57 Bulu-bulu Kecamatan Marusu Kabupaten Maros
\end{abstract}

Kata kunci : Hubungan minat baca; prestasi pelajar Bahasa Indonesia 


\section{PENDAHULUAN}

Kemampuan membaca dan minat membaca yang tinggi adalah modal dasar untuk keberhasilan anak dalam berbagai mata pelajaran. Kemampuan membaca dapat diperoleh melalui pendidikan formal dan informal. Pendidikan formal yaitu Sekolah Dasar, Sekolah Menengah Pertama, dan Sekolah Menengah Atas. Salah satunya pada mata pelajaran Bahasa Indonesia. Dimana, pada mata pelajaran Bahasa Indonesia, siswa dituntut untuk memiliki banyak wawasan tentang keilmuan Bahasa. Minat membaca dalam hal ini adalah minat membaca siswa kelas VI SD Negeri 57 Bulu-bulu.

Minat baca dalam masyarakat kita mulai merangkak meskipun belum mencapai tahapan yang signifikan. Minat ini perlu ditumbuhkembangkan terus menerus untuk mencapai masyarakat yang cerdas secara religi, intelektual, sosial, dan ekonomi. Sebab membaca merupakan pintu gerbang informasi dan ilmu pengetahuan dan pendukung kecerdasan bangsa. Dengan membaca sejumlah literatur, diskusi, dan mengikuti pertemuan ilmiah, sesorang mampu mengasah otak, memperoleh wawasan, dan meningkatkan ilmu pengetahuan. Bacaan besar pengaruhnya terhadap pembentukan pribadi dan kemajuan bangsa. Kiranya tidak ada sejarah yang mencatat kehebatan seseorang yang tidak dibarengi dengan gemar membaca dan melek informasi dalam arti luas. Karena itu membaca sangatlah penting dalam perkembangan seorang anak (Siahaan, 2007:166).

Kondisi minat baca bangsa kita masih jauh tertinggal dari minat baca bangsa lain. Dari beberapa survei dan penelitian menunjukkan kondisi tersebut. Hal ini antara lain dibuktikan dengan rasio surat kabar dibanding dengan jumlah penduduk. Untuk itu dapat dicermati rasio surat kabar dan penduduk di negara-negara Asean seperti Filipina 1:30, Sri Lanka $1: 38$ dan Indonesia 1: 45. Padahal rasio surat kabar dan jumlah penduduk di negara-negara maju telah mencapai rasio $1: 10$. Kondisi ini sangat mungkin bahwa kita bangsa Indonesia ini masih kuat tradisi kelisanannya (Siahaan 2007: 168).

Membaca merupakan proses penyerapan informasi yang lebih efektif dari pada mendengar. Hal ini akan berpengaruh positif terhadap kreativitas seseorang. Dalam hal ini Marion Lawrence yang dikutip Wendyataka (2003:46) mengemukakan hasil penelitiannya bahwa anak hanya mampu mengingat $10 \%$ dari yang didengarnya, $50 \%$ dari yang dilihat/ baca, 70 \% dari yang dikatakannya, dan $90 \%$ dari yang dilakukannya. Membaca merupakan usaha penyebaran gagasan dan upaya kreatif. Siklus membaca sebenarnya merupakan siklus mengalirnya ide pengarang ke dalam diri pembaca yang pada gilirannya akan mengalir ke seluruh penjuru dunia melalui tulisan (buku, artikel, makalah seminar, hasil penelitian) dan rekaman lain. Mengembangkan minat baca pada anak, akan diperoleh generasi muda yang gemar membaca yang mempunyai wawasan luas serta kemampuan berpikir tinggi, penguasaan terhadap ilmu dan teknologi. 
Kenyataannya ditemukan adanya gejala malas membaca pada generasi muda kita, khususnya pada anak-anak di tingkat Sekolah Dasar (SD), bahwasanya mereka lebih suka mengisi waktu luangnya untuk bermain ataupun menonton televisi dari pada menggunakan waktu luangnya unuk membaca. Hal ini disebabkan oleh beragamnya sarana hiburan yang menjanjikan anak untuk dapat bersenang-senang. Adanya mainan-mainan yang modern dan juga acara hiburan telivisi yang menarik serta pengaruh media sosial yang semakin besar merupakan salah satu faktor penyebab berkurangnya minat baca pada anak (Lasa, 2009: Volume 11 Nomor 2).

Seiring dengan perubahan paradigma pembelajaran, maka keberhasilan kegiatan proses belajar mengajar tidak hanya ditentukan oleh faktor pengajar melainkan sangat dipengaruhi oleh keaktifan siswa dalam mencari sumber belajar. Selain sumber belajar berupa perpustakaan yang tersedia di sekolah, sekarang ini berkembang teknologi internet yang memberikan kemudahan dan keleluasaan dalam menggali ilmu pengetahuan. Melalui internet siswa dapat mengakses berbagai literatur dan referensi ilmu pengetahuan yang dibutuhkan dengan cepat sehingga dapat mempermudah proses belajar (Mulyasa, 2003: 36).

Sumber belajar atau Learning resources adalah semua sumber baik berupa data, orang dan wujud tertentu yang dapat digunakan oleh peserta didik dalam menunjang proses belajar, sehingga mempermudah perserta didik dalam mencapai tujuan belajar atau mencapai kompetensi tertentu. Sumber belajar tidak hanya bisa diambil melalui media cetak, tetapi juga internet dengan sumber belajar tersebut peserta didik diharapkan dapat memperoleh ilmu dengan cepat dan terbaru, sehingga prestasi belajar peserta didik menjadi baik dan meningkat (Mulyasa, 2003: 34).

Berdasarkan uraian latar belakang di atas, maka penulis tertarik untuk melakukan penelitian dengan judul "Hubungan Minat Baca dengan Prestasi Belajar Bahasa indonesia bagi Siswa Kelas VI SD Negeri 57 Bulu-bulu Kecamatan Marusu Kabupaten Maros".

Berdasarkan uraian di atas rumusan masalah dalam penelitian ini adalah “Adakah hubungan minat baca dengan prestasi belajar bahasa Indonesia siswa kelas VI SD Negeri 57 Bulu-Bulu Kec. Marusu Kabupaten Maros ?".Tujuan penelitian ini adalah mengetahui "Untuk mendeskripsikanhubungan minat baca dengan prestasi belajar bahasa Indonesia siswa kelas VI SD Negeri 57 Bulu-Bulu Kec. Marusu Kabupaten Maros"

\section{Minat dan Upaya Meningkatkan Minat Baca}

Menurut Mappiare (1983:62) minat adalah perangkat mental yang terdiri dari suatu campuran perasaan, harapan, pendirian, perasangka, rasa tajut atau kecenderungan lain yang mengarahkan individu kepada suatu pilihan tertentu.Jadi, 
minat adalah suatu unsur kepribadian individu yang memegang peranan penting dalam pengambilan keputusan.

Minat dalam diri seseorang tampak pada kecenderungan perilaku pada subjek tertentu. Rasa senang dan kondisi kejiwaan lain yang diperlihatkan seseorang dalam merespons sesuatu yang dihadapinya atau yang ada disekitarnya. Seorang siswa yang berminat pada suatu objek tertentu, maka dai akan berusaha menekuni objek tersebut.

Seperti lingkungan sekolah yang mempunyai sarana dan prasarana yang lengkap (memadai) maka biasanya minat siswa dapat timbul. Sebagai contoh, jika buku-buku bahasa Indonesia sangat banyak di perpustakaan tersedianya laboratorium bahasa yang memadai, maka ini akan mempengaruhi minat siswa pada bidang studi bahasa Indonesia.

Jadi, peranan minat dalam membaca menduduki posisi yang sangat sentral dan penting, karena merupakan salah satu faktor alasan pendorong yang sangat kuat pada diri seseorang untuk berbuat dan meningkatkan keberhasilan aktivitas membaca. Atau dengan perkataan lain peranan minat dalam membaca menduduki tempat yang sangat penting, karena ia merupakan sumber pemicu utama seseorang dalam melakukan aktivitas membaca. Oleh karena itu, para guru di sekolah serta para orang tua di rumah seyogyanya lebih memahami benar seputar persoalan minat baca ini, khususnya terhadap aneka upaya untuk menumbuhkannya.

\section{Hakekat dan Pengertian Membaca}

Menurut Samsuri (1989:5), Aku berbahasa, karena aku hidup. Bahasa di samping merupakan hasil budaya juga sebagai alat budaya, bahasa merupakan produk manusia dalam pengertian bahasa sebagai objek studi atau objek penelitian. Sebagai alat budaya, bahasa berfungsi sebagai simbol budaya.

Membaca pada hakekatnya merupakan suatu kesinambungan yang berlangsung secara bertahap, berproses dari yang sederhana hingga yang lebih rumit. Hasil yang cemerlang dari sebuah proses membaca yaitu kesan pertama. Namun, yang paling penting adalah kemampuan seseorang dalam memproses hal tersebut. Seseorang harus menguasai cara membaca karena kemampuan membaca akan menjadi alat pokok ketika seseorang telah menghadapi sumber-sumber yang berhubungan dengan membaca yang dibutuhkan.Penelitian ini hanya akan mengkhususkan pembelajaran membaca yang bersifat pemahaman. 
Said (1991:12) menyatakan, tujuan pembelajaran membaca ialah untuk memahami arti keseluruhan wacana, menemukan isi bacaan secara terperinci, dan mampu memahami isi bacaan baik yang tersurat maupun yang tersirat.

Tarigan (1989: 84-87) menyatakan bahwa: Tujuan membaca khusus di sekolah adalah (a) dapat meningkatkan kemampuan membaca, yang memperhatikan pada analisis struktural kata-kata dan kemampuan pemahaman yang disusun secara sistematis, menginterprestasi, mengevaluasi serta mengapresiasi apa yang telah dibaca, (b) mengembangkan kepasifan membaca, (c) bagaimana siswa dapat menyesuaikan bacaan dengan materi melalui permasalahan.

Jadi, sesuai dengan apa yang telah dipaparkan di atas mengenai tujuan membaca, maka dapat disimpulkan secara umum bahwa tujuan membaca adalah sebagai alat untuk memperluas pengalaman yang merupakan minat dan menyesuaikan materi bacaan.

\section{Prestasi Belajar}

Dalam kehidupan sehari-hari, manusia selalu dituntut untuk mengubah pola kehidupannya menjadi taraf yang lebih baik. Proses perubahan itu baik dalam bentuk kognitif atau efektif.

Menurut Nurwahidah (1996:19), prestasi adalah berhasil menunjukkan kecakapan suatu bangsa atau manusia. Jadi, seorang dikatakan berprestasi apabila terbukti bahwa dia mempunyai kecakapan yang diukur melalui hasil pekerjaannya. Sedangkan pekerjaan yang berhasil biasanya dilandasi rasa kecintaan dan kesenangan pada objek (pekerjaan tersebut). Jadi, cara mengukur kemajuan anak yang paling tepat adalah dengan melihat bagaimana proses perubahan itu berlangsung konstan dan terarah dalam diri seseorang.

Seorang siswa yang berprestasi pada suatu disiplin ilmu tertentu, biasanya dia menyenangi disiplin ilmu itu. Karena kecintaannya, sehingga di luar jam pelajaran dia akan mencari segala sesuatu yang berhubungan dengan disiplin ilmu yang digelutinya itu.

Tetapi tidak dapat dipungkiri pula bahwa ada siswa yang berprestasi karena daya ingat yang kuat saat pelajaran berlangsung, siswa yang berkonsentrasi penuh pada saat pelajaran berlangsung, biasanya menunjukkan prestasi yang baik dibandingkan dengan siswa yang tidak berkonsentrasi. Jadi, prestasi juga didorong oleh daya ingat yang kuat. 


\section{METODE PENELITIAN}

Penelitian ini merupakan penelitian korelasional dengan menggunakan kuantitatif. Desain penelitian yang digunakan dalam penelitian ini adalah deskriptif karena sasarannya untuk menggambarkan korelasi, yang bertujuan untuk mengetahui hubungan antara minat baca dan prestasi belajar Bahasa Indonesia siswa kelas VI SD Negeri 57 Bulu-Bulu Kecamatan Marusu Kabupaten Maros.

Populasi dalam penelitian ini adalah murid kelas VI SD Negeri 57 Bulu-bulu Kecamatan Marusu Kabupaten Maros yang berjumlah 37 orang. sampel dalam penelitian ini adalah bagian dari populasi, yaitu murid kelas VI SD Negeri 57 bulu-bulu yang berjumlah 37 orang. Instrumen yang digunakan dalam penelitian ini adalah berupa angket. Analisis data yang digunakan uji korelasi dan uji hipotesis.

\section{HASIL PENELITIAN DAN PEMBAHASAN}

Hasil penelitian mengenai minat baca siswa yang diperoleh dari hasil instrument angket dan hasil belajar siswa dari hasil tes yang diberikan kepada siswa setelah siswa membaca secara berturut-turut akan dianalisis dengan analisis statistik deskriptif.

\section{Analisis Statistik deskriptif}

Analisis statistik deskriptif dimaksudkan untuk menggambarkan minat baca siswa dengan hasil belajar siswa kelas VI SD Negeri 57 Bulu-bulu Kecamatan Marusu Kabupaten Maros dengan menggunakan tabel distribusi frekuensi dan persentase.

a. Minat Baca

Untuk memperoleh gambaran tentang minat baca, maka diklasifikasikan atas 5 (lima) kategori yaitu: sangat rendah, rendah, sedang, tinggi dan sangat tinggi. Lebih jelasnya dapat dilihat pada tabel distribusi frekuensi dan persentase berikut:

Tabel 1. Distribusi dan Persentase Minat Baca Kelas VI SD Negeri 57 Bulu-bulu Kecamatan Marusu Kabupaten Maros

\begin{tabular}{|c|c|c|c|}
\hline Inteval & Kualifikasi & Frekuensi & Persentase \\
\hline $0-34$ & Sangat rendah & 0 & 0 \\
$35-54$ & Rendah & 7 & $18,92 \%$ \\
$55-64$ & Sedang & 23 & $62,16 \%$ \\
$65-84$ & Tinggi & 7 & $18,92 \%$ \\
\hline
\end{tabular}




\begin{tabular}{|c|c|c|c|}
\hline $85-100$ & Sangat tinggi & 0 & 0 \\
\hline \multicolumn{2}{|c|}{ Jumlah } & $\mathbf{3 7}$ & $\mathbf{1 0 0 \%}$ \\
\hline
\end{tabular}

Dari hasil perhitungan di dapat nilai rata-rata yaitu 58,08. Berdasarkan tabel distribusi frekuensi dan persentase motivasi belajar menunjukkan bahwa secara umum siswa kelas VI di SD Negeri 57 Bulu-bulu Kecamatan Marusu Kabupaten Maros sudah memiliki minat baca yang baik, seperti yang tercantum pada tabel tersebut di atas yaitu berada pada interval 35-54 (rendah) dengan frekuensi 7 orang, interval 5564 (sedang) dengan frekuensi 23, dan interval 65-84 (tinggi) dengan frekuensi 7 orang. Artinya selama ini siswa memiliki minat baca yang baik dalam kegiatan belajar mengajarnya.

b. Prestasi Belajar

Untuk memperoleh gambaran tentang prestasi belajar siswa SD Negeri 57 Bulu-bulu Kecamatan Marusu Kabupaten Maros, maka diklarifikasikan atas 5 (lima) kategori yaitu: sangat rendah, rendah, sedang, tinggi dan sangat tinggi.

Tabel 2. Distribusi Frekuensi dan Persentase Prestasi Belajar Siswa Kelas VI SD Negeri 57 Bulu-bulu Kecamatan Marusu Kabupaten Maros

\begin{tabular}{|l|l|l|l|}
\hline Inteval & Kualifikasi & Frekuensi & Persentase \\
\hline $0-34$ & Sangat rendah & 0 & 0 \\
$35-54$ & Rendah & 1 & $2,70 \%$ \\
$55-64$ & Sedang & 1 & $2,70 \%$ \\
$65-84$ & Tinggi & 21 & $56,76 \%$ \\
$85-100$ & Sangat tinggi & 14 & $37,84 \%$ \\
\hline Jumlah & & $\mathbf{3 7}$ & $\mathbf{1 0 0 \%}$ \\
\hline
\end{tabular}

Berdasarkan tabel di atas, maka siswa kelas VI SD Negeri 57 Bulu-bulu Kecamatan Marusu Kabupaten Maros memiliki rata-rata prestasi sebesar 80,14 . Hal tersebut menunjukkan bahwa hasil belajar siswa kelas VI SD Negeri 57 Bulu-bulu Kecamatan Marusu Kabupaten Maros tergolong tinggi, seperti yang tercantum pada tabel di atas yaitu berada pada interval 35-54 dengan frekuensi 1 orang, interval 55-64 
dengan frekuensi 1 orang, interval 65-84 dengan frekuensi 21 orang, dan interval 85100 dengan frekuensi 14 orang.

\section{Analisis koefisiensi korelasi}

a. Korelasi X dengan Y

Untuk menghitung korelasi antara variabel $\mathrm{X}$ dengan variabel $\mathrm{Y}$, maka peneliti menggunakan software SPSS tipe 16. Adapun hasil analisis korelasi antara variabel X dengan variabel $Y$ dapat dilihat pada tabel 3 berikut.

\section{Tabel 3 Hasil Analisis Korelasi Variabel X dengan Variabel Y}

\section{Correlations}

\begin{tabular}{|ll|l|l|}
\hline & & $\mathbf{X}$ & $\mathbf{Y}$ \\
\hline $\mathbf{X}$ & $\begin{array}{l}\text { Pearson } \\
\text { Correlation } \\
\text { Sig. (2-tailed) } \\
\text { N }\end{array}$ & 1 & $.738^{* *}$ \\
\hline Y & Pearson & .000 \\
& Correlation \\
& Sig. (2-tailed) & .000 & 37 \\
N & 37 & 37 \\
\hline **. Correlation is significant at the 0.01 level \\
(2-tailed).
\end{tabular}

Berdasarkan hasil output SPSS pada tabel 4.3 di atas, dapat dilihat bahwa variabel X dan variabel Y memiliki nilai korelasi sebesar 0,738. Hal ini berarti, dapat diketahui bahwa $r_{\text {hitung }}=0,738$. Apabila dikonsultasikan dengan tabel $\mathrm{r}$ product moment dengan jumlah sampel $\mathrm{n}=37$, pada taraf signifikan $1 \%$ diperoleh $r_{\text {tabel }}=$ 0.418. Jika $r_{\text {hitung }}<r_{\text {tabel }}$ maka Ho (diterima) dan Ha (ditolak). Tapi sebaliknya jika $r_{\text {hitung }}>r_{\text {tabel }}$ maka Ha (diterima) dan Ho (ditolak).

Hasil yang diperoleh peneliti, $r_{\text {hitung }}(0,738)$ lebih besar dari $r_{\text {tabel }}(0.418)$, hal ini menunjukkan bahwa Ha (diterima) dan Ho (ditolak) dengan artian terdapat 
hubungan yang signifikan antara minat baca dengan prestasi belajar siswa kelas VI SD Negeri 57 Bulu-bulu Kecamatan Marusu Kabupaten Maros.

Minat baca yang dimiliki oleh siswa kelas VI SD Negeri 57 Bulu-bulu Kecamatan Marusu Kabupaten Maros berada pada kualifikasi yang baik baik, hal tersebut berdasarkan perhitungan rata-rata yang diperoleh sebesar 58,08. Begitu pula halnya dengan hasil belajar siswa termasuk dalam kategori tinggi dengan tingkat rata-rata 80,14

Dari hasil penelitian ini dapatlah dibuktikan bahwa minat baca siswa memegang peranan penting dalam upaya peningkatan hasil belajar siswa. Tingginya minat baca siswa merupakan wahana utama mencapai tujuan pendidikan, yang menentukan mutu pendidikan nasional.

Minat baca siswa erat hubungaannya dengan kerajinan siswa dalam membaca dan juga dalam belajar. Dengan demikian, agar siswa belajar lebih maju maka siswa harus meningkatkan minat bacanya yang nantinya dapat mempengaruhi prestasi belajarnya baik disekolah, rumah ataupun di perpustakaan.

Minat adalah suatu unsur kepribadian individu yang memegang peranan penting dalam pengambilan keputusan. Minat mengarahkan tindakan individu terhadap suatu objek atas dasar rasa senang atau tidak senang, suka atau tidak suka. Minat seseorang dapat diketahui dari pernyataan senang dan tidak senang dan suka atau tidak suka terhadap objek tertentu. Tingginya minat seseorang terhadap suatu hal tentunya akan membawa dampak yang besar pula bagi orang tersebut. Hal ini berarti, jika minat baca siswa tinggi, maka prestasi belajar siswa juga akan baik. Begitupun sebaliknya.

Oleh karena itu minat baca sangat berperan terhadap hasil belajar Siswa. Dengan minat baca yang tinggi, akan membuat siswa rajin membaca. Minat yang baik akan memungkinkan untuk memperoleh serta mendapatkan prestasi dari setiap individu yang beraktifitas, lebih-lebih dalam korelasinya dengan hasil belajar.

Dengan minat baca memiliki keterkaitan yang kuat dengan hasil belajar sehingga dapatlah disimpulkan bahwa semakin tinggi minat baca siswa, maka akan semakin tinggi pula hasil belajar yang dicapai siswa. Begitu pula sebaliknya, semakin kurang minat siswa, maka akan rendah pula hasil belajarnya.

Dari uraian di atas dapat dikertahui bahwa minat baca mempunyai hubungan dengan hasil belajar siswa, hal tersebut dapat dilihat dari nilai rhitung yang diperoleh 
sebesar 0,738, pada taraf signifikan 1\% diperoleh $r_{\text {tabel }}=0.418$. Dengan demikian, $r_{\text {hitung }}<r_{\text {tabel }}$ maka Ho (diterima) dan Ha (ditolak). Berarti terdapat hubungan yang sifnifikan antara minat baca dengan prestasi belajar siswa kelas VI SD Negeri 57 Bulubulu Kecamatan Marusu Kabupaten Maros.

\section{SIMPULAN DAN SARAN}

Berdasarkan hasil kelas VI SD Negeri 57 Bulu-bulu Kecamatan Marusu Kabupaten Maros yang mengkaji tentang hubungan minat baca siswa dengan prestasi belajar Bahasa Indonesia, maka peneliti dapat menarik kesimpulan sebagai berikut:

1. Minat baca siswa kelas VI SD Negeri 57 Bulu-bulu Kecamatan Marusu Kabupaten Maros secara umum berlangsung dengan sangat baik yakni berdasarkan perhitungan rata-rata yang diperoleh sebesar 58,08 yang berada pada kategori sedang.

2. Prestasi belajar siswa kelas VI SD Negeri 57 Bulu-bulu Kecamatan Marusu Kabupaten Maros secara umum dalam kategori tinggi, yakni dengan tingkat ratarata 80,14, yaitu berada pada interval 65 - 84 ( kategori tinggi).

Hal ini berarti, terdapat hubungan yang signifikan antara minat baca dengan prestasi belajar Bahasa Indonesia siswa kelas VI SD Negeri 57 Bulu-bulu Kecamatan Marusu Kabupaten Maros, dimana dalam penelitian ini di peroleh nilai rhitung 0,738 dengan taraf signifikansi $1 \%$ dengan $r$ tabel sebesar 0,418 . Dengan demikian, $r_{\text {hitung }}<$ $r_{\text {tabel }}$ maka Ho (diterima) dan Ha (ditolak).

Saran yang dapat diberikan: (1) guru IPA diharapkan dapat menerapkan model inkuiri terbimbing tidak hanya dalam materi Magnet tetapi pada materi lain yang sesuai; (2) perlu dilakukan uji coba lebih luas terhadap produk model yang dihasilkan dalam pembelajaran IPA di sekolah dasar; (3) Guru dalam menggunakan perangkat ini dapat memperhatikan langkah-langkah atau kegiatan pembelajaran serta aspek-aspek yang mempengaruhi kualitas pembelajaran sehingga memudahkan peserta didik dalam proses pembelajaran.

\section{DAFTAR PUSTAKA}

Arikunto, Suharsini. 1993. Prosedur Penelitian. Jakarta: Rineka Cipta. 
Emzir. 2007. Metodologi Penelitian Pendidikan:Kuantitatif dan Kualitatif. Jakarta: PT Raja Grafindo Persada.

Ginting.Pengertian minat baca www.bpkpenabur.or.id

Hadi, Sutrisno. 1989. Statistika II. Yogyakarta: UGM

Hanafie, Sitti Hawang. 1998. "Baca Cepat dan Efektif". Alternatif dan Alih Informasi dalam Meningkatkan Sumber Daya Manusia pada Era Informasi dan Kesejagatan (Globalisasi). Orasi. Penerimaan Jabatan Guru Besar pada Tanggal 24 Oktober 1990. Ujung Pandang: FPBS IKIP.

Harras. 1989. MembacaI.Jakarta: Depdikbud.

Htttp://id.m.wikipedia.org/wiki/hubungan

Isda.2011. Hubungan Antara Kebiasaan Membaca dengan Kemampuan Membaca Pemahaman Murid Kelas VI SD Pajjaiang.

Mappiare. 1983. Psikologi Remaja. Surabaya: Usaha Nasional.

Mirnawati.2015. Hubungan Disiplin Belajar dengan Prestasi Belajar Siswa Kelas V SD Inpres Lae-Lae Kota Makassar.

Nurhadi. 1987. Membaca Cepat dan Efektif. Jakarta: Erlangga.

Nurwahidah. 1996. Hubungan antara Kemampuan Menulis dan Prestasi Belajar Siswa Kelas III SMP Negeri Batangase Mandai. Skripsi. Ujung Pandang: FPBS IKIP.

Rohani, dkk. 1990. Pengelolaan Pengajaran. Jakarta: Rineka Cipta.

Said, Ide. 1991. "Membaca”. Bahan Sajian Kuliah. Ujung Pandang: FPBS IKIP.

Samsuri. 1989. Analisis Bahasa. Jakarta: Erlangga.

Sudarsono. 1988. Sistem Membaca Cepat dan Efektif. Jakarta: Gramedia.

Sukardi, Ketut. 1982. Tes dalam Konseling Karier. Surabaya: Usaha Nasional.

Sutjarso, Adi S. 1990. "Tingkat Penguasaan Kosakata Bahasa Indonesia Murid Kelas VI SD Negeri Mattoanging 2 Ujung Pandang Berdasarkan Latar Belakang bahasa Ibu". Laporan Penelitian. Ujung Pandang: Pusat Penelitian IKIP.

Tarigan. Henry Guntur. 1989. Membaca sebagai Suatu Keterampilan. Bandung: Angkasa. 